\title{
OPTIMALISASI PEMELIHARAAN YUWANA ABALON (H. squamata) DENGAN KEPADATAN DAN JENIS PAKAN YANG BERBEDA
}

\author{
Bambang Susanto, Ibnu Rusdi, dan I Nyoman Adiasmara Giri \\ Balai Besar Penelitian dan Pengembangan Budidaya Laut \\ Jl. Br. Gondol Kec. Gerokgak Kab. Buleleng, Kotak Pos 140, Singaraja- Bali 81101 \\ E-mail: bambang_ssnt@yahoo.com
}

(Naskah diterima: 8 November 2011; Disetujui publikasi: 8 Maret 2012)

\begin{abstract}
ABSTRAK
Optimalisasi pemeliharaan yuwana abalon telah dilakukan dengan tiga berbeda kepadatan dan memanfaatkan tiga jenis rumput laut. Tujuan penelitian ini adalah untuk memperoleh teknik pemeliharaan yuwana abalon $H$. squamata yang efisien dan aplikatif melalui kepadatan dan jenis pakan yang berbeda. Digunakan yuwana abalon dengan ukuran panjang cangkang awal 7,8-10,1 mm; kepadatan yuwana awal yaitu 500, 250, dan 125 ekor/keranjang, dan jenis pakan yang berbeda yaitu Ulva sp., Gracilaria sp. asal laut, dan Gracilaria sp. asal tambak. Hasil yang dicapai pada akhir penelitian menunjukkan pengaruh yang nyata $(P<0,05)$ terhadap pertumbuhan panjang cangkang, di mana pada perlakuan (A) 500 ekor + Gracilaria asal tambak sebesar 15,07 $\pm 3,08 \mathrm{~mm}$; (B) 500 ekor + Ulva sebesar 13,58 $\pm 2,65 \mathrm{~mm}$; (C) 500 ekor + Gracilaria asal laut sebesar

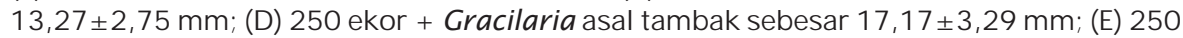
ekor + Ulva sebesar 16,44 $\pm 2,90 \mathrm{~mm}$; (F) 250 ekor + Gracilaria asal laut sebesar 16,08 $\pm 3,21 \mathrm{~mm}$; (G) 125 ekor + Gracilaria asal tambak sebesar 17,94 $\pm 2,49$ mm; (H) 125 ekor + Ulva sebesar 18,65 $\pm 2,72 \mathrm{~mm}$; (I) 125 ekor + Gracilaria asal laut 17,87 $\pm 3,16 \mathrm{~mm}$. Sintasan yuwana abalon pada akhir penelitian berkisar antara $84 \%$ sampai $99 \%$
\end{abstract}

\section{KATA KUNCl: yuwana, kepadatan, makroalga, abalon}

ABSTRACT: Optimization of abalone juvenile (H. squamata) rearing with various densities and foods. By: Bambang Susanto, Ibnu Rusdi, and I Nyoman Adiasmara Giri

Optimization of juvenile abalone rearing has been carried out in three stocking densities and use of three macroalgae species as food. The purpose of this study was to obtain the best rearing techniques of abalone $\boldsymbol{H}$. squamata juvenile. Used juvenile abalone were initially with shell lengths from 7.8 to $10.1 \mathrm{~mm}$, juvenile densities of 500, 250, and 125 animals per basket and fed with Ulva sp., Gracilaria sp. (origin from the sea), and Gracilaria sp. cultured from the pond. The results showed significant effect $(P<0.05)$ on the growth of shell length: $(A) 500$ pcs + Gracilaria sp. cultured from the pond at $15.07 \pm 3.08 \mathrm{~mm}$, (B) $500 \mathrm{pcs}+$ Ulva at $13.58 \pm 2.65 \mathrm{~mm}$; (C) $500 \mathrm{pcs}$ + Gracilaria sp. (origin from the sea) at $13.27 \pm 2.75 \mathrm{~mm}$, (D) $250 \mathrm{pcs}$ + Gracilaria sp. cultured from the pond at $17.17 \pm 3.29 \mathrm{~mm}$; (E) $250 \mathrm{pcs}+$ Ulva at $16.44 \pm 2.90 \mathrm{~mm}$, (F) 250 pcs + Gracilaria sp. (origin from the sea) at $16.08 \pm 3.21 \mathrm{~mm}$; (G) $125 \mathrm{pcs}+$ Gracilaria sp. cultured from the pond at $17.94 \pm 2.49 \mathrm{~mm}$, (H) $125 \mathrm{pcs}+$ Ulva at $18.65 \pm 2.72 \mathrm{~mm}$; (I) $125 \mathrm{pcs}+$ origin from the sea of Gracilaria at $17.87 \pm 3.16 \mathrm{~mm}$. Survival rates of abalone juvenile at the end of the study ranged from $84 \%-98 \%$.

KEYWORDS: juvenile, densities, macroalgae, $H$. squamata 


\section{PENDAHULUAN}

Abalon (Haliotis spp.) tergolong ke dalam kelas Gastropoda, famili Haliotidae. Di alam dilaporkan terdapat sekitar 100 spesies yang berasal dari genus Haliotis, namun yang memiliki nilai komersil hanya sekitar 10 spesies (Takashi, 1980; Fallu, 1991). Pembenihan abalon di Indonesia sudah mulai dilakukan terhadap 3 spesies, yaitu Haliotis asinina, $H$. diversicolor, dan $H$. squamata, sedangkan di Jepang dilaporkan terdapat 7 spesies, yaitu $H$. asinina, $H$. gigantea, $H$. sieboldii, $H$. discus, $H$. discus hannai, $H$. diversicolor, dan $H$. supertexta (Ikenoue \& Kafuku, 1992).

Abalon dilaporkan banyak ditemukan pada beberapa perairan Indonesia, terutama pada daerah pantai yang berkarang, seperti di perairan Nusa Tenggara Barat, Madura, Jawa Timur, Ambon, dan Sulawesi Selatan. Abalon berukuran cangkang lebih besar $( \pm 19 \mathrm{~cm})$ ditemukan di perairan Sumba dan Timor, sedangkan spesies $H$. squamata dilaporkan banyak ditemukan di perairan Selatan Bali dan Jawa (Priyambodo et al., 2005; Rusdi et al., 2008). Abalon termasuk hewan yang bersifat endemik, pada stadia larva memakan diatom bentik, sedangkan abalon dewasa di alam memakan makroalga yang terbagi atas tiga golongan, yaitu alga coklat, hijau, dan merah. Jenis alga merah Gracilaria sp. merupakan jenis pakan yang dilaporkan baik untuk abalon spesies H. asinina (Singhagraiwan \&Doi, 1993; Capinpin \& Corre, 1996) dan H. squamata (Susanto et al., 2007). Namun dilaporkan juga bahwa abalon $H$. squamata sangat menyukai jenis alga lunak seperti Ulva sp. dan memberikan respons yang cukup baik terhadap pertumbuhan (Rahmawati et al., 2008).

Saat ini di Balai Besar Penelitian dan Pengembangan Budidaya Laut, Gondol telah berhasil memproduksi benih abalon $H$. squamata skala massal di hatcheri dengan perolehan sintasan benih umur 2 bulan mencapai 18,4\%(Susanto et al., 2009). Kendala yang masih dihadapi dalam upaya produksi benih abalon skala massal adalah dalam penyediaan pakan makroalga secara berkesinambungan. Di sisi lain, yuwana abalon yang dihasilkan masih memerlukan perbaikan sistem pendederan, diantaranya dengan mengevaluasi padat tebar yang optimal serta jenis pakan yang cocok dan dapat memacu pertumbuhan benih abalon $\mathrm{H}$. squamata sebelum dibesarkan di laut. Berdasarkan permasalahan di atas, perlu dilakukan penelitian dengan tujuan untuk memperoleh teknik pemeliharaan yuwana abalon $H$. squamata yang efisien dan aplikatif melalui kepadatan dan jenis pakan yang berbeda.

\section{BAHAN DAN METODE}

Penelitian ini dilakukan dalam bak terkontrol di hatcheri abalon Balai Besar Penelitian dan Pengembangan Budidaya Laut, Gondol- Bali. Menggunakan larva abalon hasil dari proses pemijahan, kemudian dipelihara dalam wadah/ bak semen volume $5-10 \mathrm{~m}^{3}$ yang dilengkapi dengan "feeding plate" plastik bergelombang yang berfungsi sebagai substrat dan tempat tumbuhnya mikroalga sebagai pakan larva. Padat tebar larva/ veliger berkisar 25- 50 ekor/ L.

Pemeliharaan Iarva abalon dari hari ke- 0 (D- 0) sampai D- 7 tidak dilakukan pergantian air, kemudian pada D- 8 mulai dilakukan pergantian air 50\% 100\%selama 24 jam dengan sistem air mengalir. Setelah benih berumur 2030 hari maka pergantian air ditingkatkan menjadi 100\% 200\%per hari. Pemanenan benih abalon dari feeding plate dilakukan pada umur pemeliharaan 60-70 hari yang selanjutnya dipelihara dalam keranjang. Yuwana yang dihasilkan kemudian diseleksi untuk digunakan sebagai hewan uji penelitian.

Yuwana abalon dipelihara dalam 27 unit keranjang berukuran $35 \mathrm{~cm} \times 25 \mathrm{~cm} \times 8 \mathrm{~cm}$ yang dipasangkan secara berhadapan dan dijepit menggunakan potongan pipa paralon, kemudian ditempatkan pada bak semen

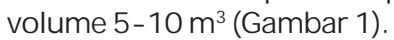

Penelitian ini menggunakan 3 perlakuan beda kepadatan dan 3 jenis pakan serta masing- masing perlakuan diulang sebanyak 3 kali. Perlakuannya adalah kepadatan yuwana 500, 250, dan 125 ekor/keranjang serta jenis pakan berbeda yaitu Ulva sp., Gracilaria sp. asal laut, dan Gracilaria sp. asal tambak. Digunakan Gracilaria sp. asal laut dan Gracilaria sp. asal tambak karena kedua rumput laut ini memiliki komposisi proksimat (Tabel 3) dan tekstur yang berbeda. Gracilaria sp. asal tambak bertekstur lebih lunak dibanding Gracilaria sp. asal laut. Percobaan dirancang dengan Rancangan Acak Kelompok (RAK) pola faktorial, yaitu: (A) 500 ekor/ keranjang + Gracilaria sp. asal tambak; (B) 500 ekor/keranjang + Ulva sp.; (C) 500 ekor/ keranjang + Gracilaria sp. asal laut; (D) 250 ekor/ keranjang + Gracilaria sp. asal tambak; (E) 250 ekor/ keranjang + Ulva sp.; (F) 250 ekor/ 

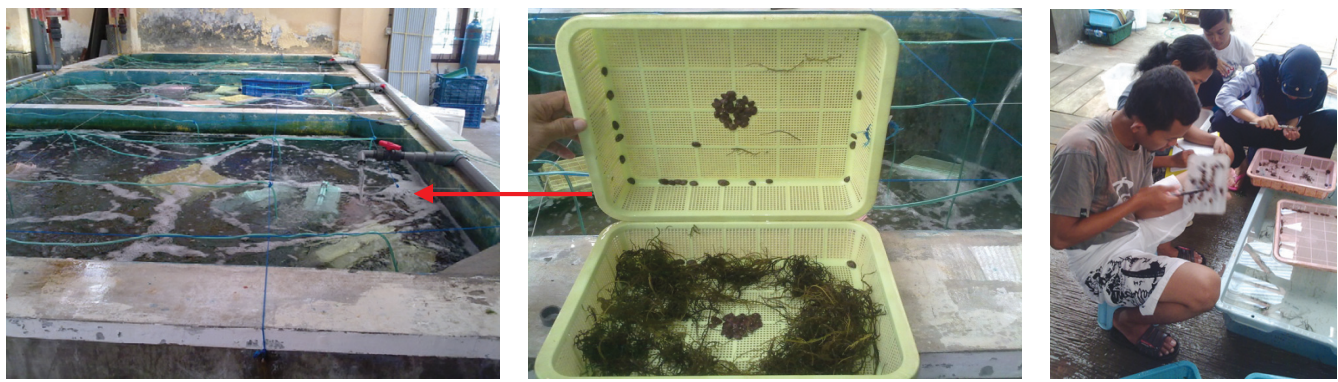

Gambar 1. Bak beton untuk pemeliharaan yuwana abalon (kiri), yuwana abalon dalam keranjang (tengah), dan seleksi benih abalon (kanan)

Figure 1. Concrete tank for the rearing of juvenile abalone (left), juvenile abalone in a basket (center), and abalone seed selection (right)

keranjang + Gracilaria sp. asal laut; (G) 125 ekor/ keranjang + Gracilaria sp. asal tambak; (H) 125 ekor/ keranjang + Ulvasp.; (I) 125 ekor/ keranjang + Gracilaria sp. asal laut. Pakan diberikan dengan dosis ad libitum dan pemeliharaan berlangsung selama 3 bulan. Pengambilan sampel parameter dilakukan setiap 15 hari dengan mengambil secara acak sesuai dengan parameter peubah yang diamati. Pengukuran panjang dan lebar cangkang abalon dilakukan menggunakan jangka sorong, sedangkan untuk penimbangan bobot badan menggunakan timbangan digital. Untuk menentukan pertumbuhan mutlak abalon menggunakan rumus Effendie (1997), dan untuk menentukan pertumbuhan harian abalon dihitung berdasarkan rumus Zhu et al. (2002):

$$
\operatorname{DISL}=\left(\mathrm{L}_{\mathrm{t}}-\mathrm{L}_{\mathrm{o}}\right) / \mathrm{T} \times 1000
$$

di mana:

DISL : Pertumbuhan harian panjang cangkang biota uji ( $\mu \mathrm{m} /$ hari)

$\mathrm{L}_{\mathrm{o}} \quad$ : Panjang cangkang rata- rata biota uji pada awal penelitian ( $\mathrm{mm}$ )

$\mathrm{L}_{\mathrm{t}} \quad$ : Panjang cangkang rata- rata biota uji pada akhir penelitian ( $\mathrm{mm}$ )

$\mathrm{T} \quad$ : Lama pemeliharaan (hari)

Sintasan abalon dihitung dengan menggunakan rumus Effendie (1997):

$$
\mathrm{SR}=\mathrm{N}_{\mathrm{t}} / \mathrm{N}_{\mathrm{o}} \times 100
$$

di mana:

SR : Sintasan hewan uji (\%)

$\mathrm{N}_{\mathrm{o}}$ : Jumlah hewan uji pada awal penelitian (ekor)

$\mathrm{N}_{\mathrm{t}}$ : Jumlah hewan uji yang hidup pada akhir penelitian (ekor)
Pengukuran beberapa parameter kualitas air pada media penelitian meliputi: suhu, salinitas, $\mathrm{pH}$, oksigen terlarut, nitrit, dan amonia. Suhu diukur menggunakan termometer digital, $\mathrm{pH}$ dengan $\mathrm{pH}$ meter, oksigen terlarut dengan DO meter, nitrit, dan amonia dengan spektrofotometer. Untuk mengetahui pengaruh perlakuan dilakukan uji statistik menggunakan software SPSS- 14 for window dan dilanjutkan dengan uji LSD (Least Significant Difference by Student's T) dan dianalisis proksimat rumput laut dan asam lemak daging abalon.

\section{HASIL DAN BAHASAN}

Hasil penelitian menunjukkan bahwa interaksi perlakuan kepadatan dan jenis pakan berbeda memberikan pengaruh nyata $(P<0,05)$ terhadap pertumbuhan panjang cangkang yuwana abalon. Di Taiwan, pertumbuhan cangkang yuwana abalon dapat meningkat sekitar 8,5 mm selama 60 hari pemeliharaan dengan pakan Gracilaria sp. (Chen, 1984 dalam Natkewatana \& Hylleberg, 1985) atau sekitar 4,25 mm/ ekor tiap bulan. Pertumbuhan abalon ( $H$. asinina) dapat meningkat sampai mencapai 0,606 cm/ bulan dengan pemberian pakan rumput laut Gracilaria sp. asal budidaya di tambak (Soleh \& Murdjani, 2007). Irwan (2006) mendapatkan peningkatan pertumbuhan panjang dan bobot masing- masing $0,199 \mathrm{~mm} /$ individu/hari dan 0,00701 g/ individu/hari yang menggunakan yuwana umur 3- 5 bulan. Ebert \& Houk (1984) dalam Natkewatana \& Hylleberg (1985) menyatakan bahwa pakan benar-benar sebagai faktor pembatas untuk pertumbuhan, dan pakan makroalga seperti rumput laut Gracilaria sp. 
sangat berperan dalam pertumbuhan benih abalon.

Dari hasil pengamatan pertambahan panjang cangkang mutlak dengan kepadatan dan jenis pakan berbeda sampai akhir penelitian terlihat bahwa pada pemberian pakan Ulva sp. cenderung lebih baik dibanding pemberian pakan Gracilaria asal tambak maupun laut, seperti pada Gambar 2.

Pertumbuhan panjang cangkang mutlak yuwana abalon yang dipelihara pada kepadatan 125 ekor/wadah dengan pemberian pakan Ulva sp. memberikan pertumbuhan mutlak yang terbaik $(9,05 \mathrm{~mm})$ diikuti dengan pemberian pakan Gracilaria asal tambak (7,60 mm) dan Gracilaria laut (7,50 mm) begitu juga pada kepadatan 250 ekor dan 500 ekor/ wadah dengan pemberian pakan Ulva sp. menunjukkan pertumbuhan panjang mutlak terbaik (Gambar 2). Hal ini diduga pakan yang dikonsumsi memiliki kandungan nutrisi yang baik untuk tumbuhnya yuwana abalon dan teksturnya lembut seperti pernyataan Chen (1984) bahwa abalon lebih menyukai pakan alga yang lembut teksturnya. Ditinjau dari teksturnya, Ulva sp. mempunyai tekstur yang lebih lunak dibandingkan dengan Gracilaria sp., sehingga abalon memerlukan energi yang lebih sedikit untuk mengkonsumsi Ulva sp. dibanding kedua jenis makroal ga tersebut. Hal ini diduga menyebabkan terjadinya perbedaan retensi energi pada tubuh abalon yang direfleksikan melalui perbedaan pertumbuhan. Apabila dilihat dari hasil analisis proksimat (Tabel 3) diketahui bahwa Ulva sp. mempunyai kadar protein dan kadar lemak yang lebih tinggi (12,64\%dan 2,57\%) jika dibandingkan dengan Gracilaria sp. (10,48\% dan 1,68\%). Kandungan protein yang ada dalam pakan dapat dimanfaatkan oleh abalon untuk meningkatkan pertumbuhan cangkangnya.

Pertumbuhan panjang cangkang yuwana abalon dari perlakuan kepadatan dan jenis pakan berbeda tersaji pada Gambar 3.

Pertumbuhan abalon dapat dilihat dari bertambahnya ukuran panjang, lebar cangkang, dan bobot badan. Cangkang yuwana abalon akan bertambah panjang seiring dengan bertambahnya umur pemeliharaan dan pakan yang dikonsumsi. Pertumbuhan dapat diartikan sebagai pertambahan jaringan akibat dari pembelahan sel secara mitosis. Pertumbuhan akan terjadi apabila ada kelebihan input energi dan asam amino (protein) berasal dari makanan (Effendie,
1997). Oleh karena itu, pemberian jenis pakan yang tepat dan mengandung nutrisi yang cukup merupakan pendukung dalam pertumbuhan abalon. Selanjutnya menurut Bautista- Teruel et al. (1999), bahwa kebutuhan protein pada pakan haruslah sesuai, mudah dicerna, dan mengandung komposisi asam amino yang cocok untuk abalon. Neori et al. (1998); Shpigel et al. (1999); Boarder \& Shpigel (2001) menyatakan bahwa pemberian pakan Ulva sp. menunjukkan peningkatan pertumbuhan abalon yang lebih baik untuk jenis $H$. tuberculata, $H$. discus hannai, dan $H$. roei.

Dilihat dari laju pertumbuhan harian untuk panjang abalon menunjukkan bahwa pemeliharaan yuwana abalon memberikan laju pertumbuhan yang terbaik dengan pemberian pakan berupa Ulva sp. (Tabel 1).

Faktor yang mempengaruhi laju pertumbuhan salah satunya adalah kepadatan dalam wadah budidaya (Vivanco- Aranda et al., 2010). Kepadatan yang tinggi mempengaruhi terjadinya persaingan pakan dan pergerakan, sehingga energi yang dikeluarkan akan lebih tinggi jika dibandingkan dengan kepadatan yang lebih rendah.

Sintasan yuwana abalon pada kepadatan 125, 250, dan 500 ekor/ keranjang dapat dilihat pada Tabel 2 .

Hasil yang diperoleh pada akhir pemeliharaan yuwana abalon terlihat bahwa sintasan sebesar $84,13 \% 98,93 \%$ Kematian selama pemeliharaan disebabkan adaptasi awal dan stres pada saat setelah sampling. Menurut Huchette et al. (2003) dan Minh et al. (2010), bahwa pada kepadatan yang tinggi membuat pergerakan abalon terbatas untuk mendapatkan makanan karena terjadi persaingan antar yuwana abalon.

Keragaan cangkang yuwana abalon dengan berbeda pakan dan kepadatan dapat dilihat pada Gambar 4. Pada pemberian pakan rumput laut Gracilaria asal laut dan Gracilaria asal tambak menunjukkan perubahan warna cangkang menjadi coklat kemerahan, sedangkan untuk pemberian pakan rumput laut jenis Ulva sp. menunjukkan perubahan warna cangkang menjadi berwarna hijau.

\section{Analisis Proksimat dan Asam Lemak}

Hasil analisis proksimat dari rumput laut yang digunakan sebagai pakan yuwana abalon tersaji pada Tabel 3. Dari data hasil analisis 

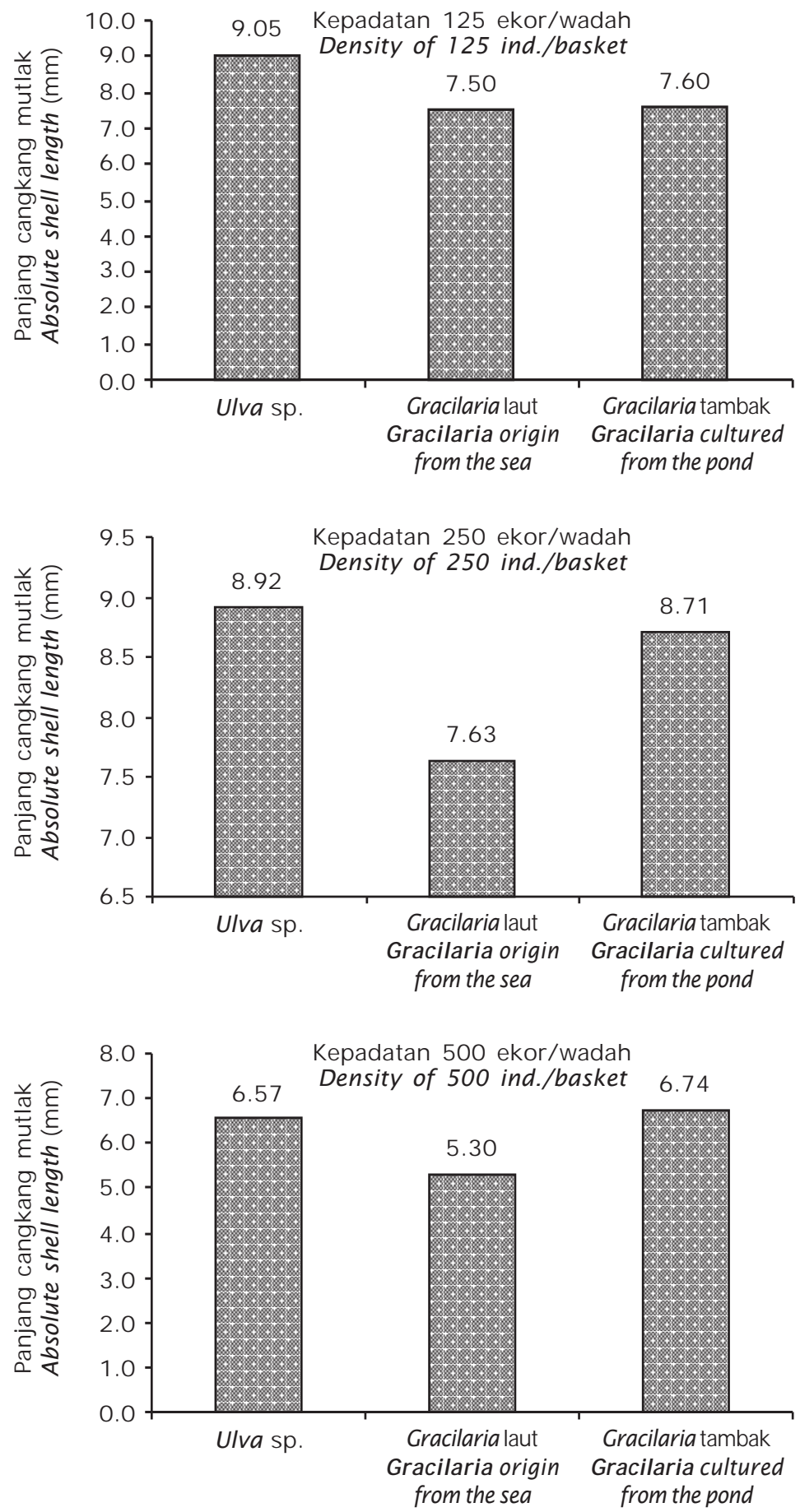

Gambar 2. Panjang cangkang mutlak yuwana abalon dengan kepadatan dan jenis pakan berbeda sampai akhir penelitian

Figure 2. Absolute shell length of abalone juvenile with different density and food various until the end of experiment 

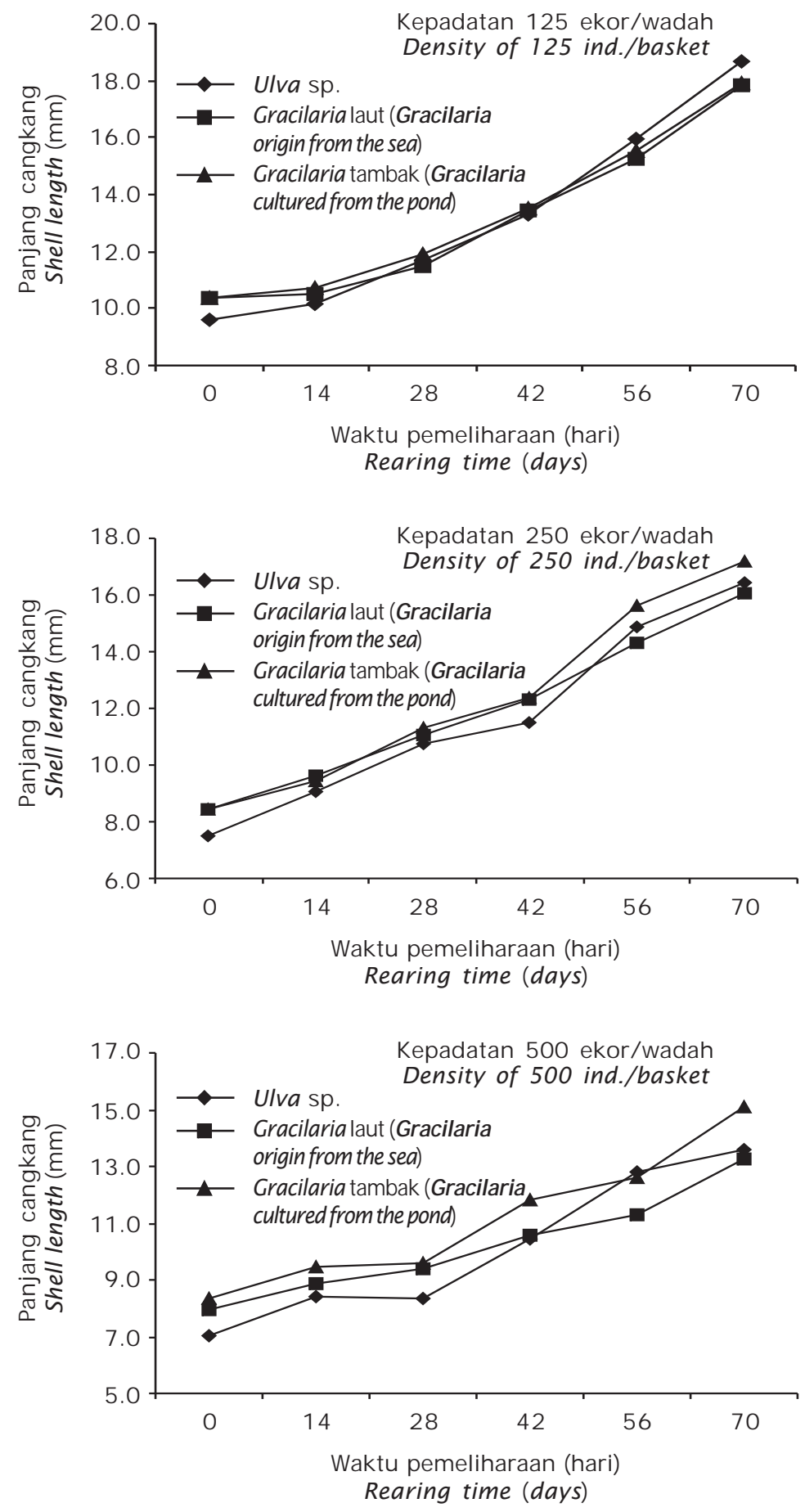

Gambar 3. Pertumbuhan panjang cangkang yuwana abalon dengan perlakuan kepadatan dan jenis pakan berbeda

Figure 3. Growth of shell length of abalone juvenile with different density and food various 
Tabel 1. Rata- rata pertumbuhan panjang cangkang harian $(\mu \mathrm{m})$ yuwana abalon pada kepadatan dan jenis pakan berbeda

Table 1. Average daily growth of abalone juvenile shell length $(\mu \mathrm{m})$ on different density and food various

\begin{tabular}{lccc}
\hline \multicolumn{1}{c}{$\begin{array}{c}\text { Pakan } \\
\text { Food }\end{array}$} & \multicolumn{3}{c}{ Kepadatan (Density) } \\
\cline { 2 - 4 } & $\begin{array}{l}\text { 500 ekor/ } \\
\text { keranjang } \\
\text { (pcs/basket) }\end{array}$ & $\begin{array}{c}\text { 250 ekor/ } \\
\text { keranjang } \\
\text { (pcs/basket) }\end{array}$ & $\begin{array}{c}\mathbf{1 2 5} \text { ekor/ } \\
\text { keranjang } \\
\text { (pcs/basket) }\end{array}$ \\
\hline $\begin{array}{l}\text { Ulva sp. } \\
\text { Gracilaria asal laut } \\
\text { Gracilaria origin from the sea }\end{array}$ & 93.87 & 127.37 & 129.26 \\
$\begin{array}{l}\text { Gracilaria asal tambak } \\
\text { Gracilaria cultured from the pond }\end{array}$ & 75.70 & 108.99 & 107.18 \\
\hline
\end{tabular}

Tabel 2. Sintasan yuwana abalon (\%) dengan kepadatan dan jenis pakan berbeda Table 2. Survival rate (\%) of abalone juvenile with different density and food various

\begin{tabular}{lccc}
\hline \multicolumn{1}{c}{$\begin{array}{c}\text { Pakan } \\
\text { Food }\end{array}$} & \multicolumn{3}{c}{ Kepadatan (Density) } \\
\cline { 2 - 4 } & $\begin{array}{c}\text { 500 ekor/ } \\
\text { keranjang } \\
\text { (pcs/basket) }\end{array}$ & $\begin{array}{c}\text { 250 ekor/ } \\
\text { keranjang } \\
\text { (pcs/basket) }\end{array}$ & $\begin{array}{c}\text { 125 ekor/ } \\
\text { keranjang } \\
\text { (pcs/basket) }\end{array}$ \\
\hline $\begin{array}{l}\text { Ulva sp. } \\
\text { Gracilaria asal laut } \\
\text { Gracilaria origin from the sea }\end{array}$ & 90.58 & 97.33 & 97.27 \\
$\begin{array}{l}\text { Gracilaria asal tambak } \\
\text { Gracilaria cultured from the pond }\end{array}$ & 96.61 & 98.93 & 96.47 \\
\hline
\end{tabular}

Tabel 3. Analisis proksimat dari rumput laut yang digunakan untuk pakan yuwana abalon Table 3. Proximate analysis of macroalgae that used for feed of abalone juvenile

\begin{tabular}{|c|c|c|c|}
\hline $\begin{array}{l}\text { Komposisi } \\
\text { Composition }\end{array}$ & $\begin{array}{c}\text { Gracilaria laut } \\
\text { Gracilaria sp. } \\
\text { cultured } \\
\text { from the sea }\end{array}$ & $\begin{array}{c}\text { Gracilaria tambak } \\
\text { Gracilaria sp. } \\
\text { cultured } \\
\text { from the pond }\end{array}$ & Ulva sp. \\
\hline Kadar protein (Protein) $(\%$ & 9.28 & 10.48 & 12.72 \\
\hline Kadar lemak (Fatty) (\%) & 1.49 & 1.81 & 2.74 \\
\hline Kadar abu (Ash) $(\%$ & 52.23 & 49.24 & 16.30 \\
\hline Kadar air (Moisture) $(\%$ & 2.14 & 4.59 & 10.06 \\
\hline
\end{tabular}

proksimat tersebut diketahui bahwa rumput laut jenis Ulva sp. mengandung protein dan lemak lebih tinggi dibandingkan dengan Gracilaria sp. Hal ini menunjukkan bahwa rumput laut Ulva sp. dapat memberikan pertumbuhan yang lebih baik dibanding pemberian pakan Gracilaria asal tambak maupun laut. Bagi abalon, protein merupakan 

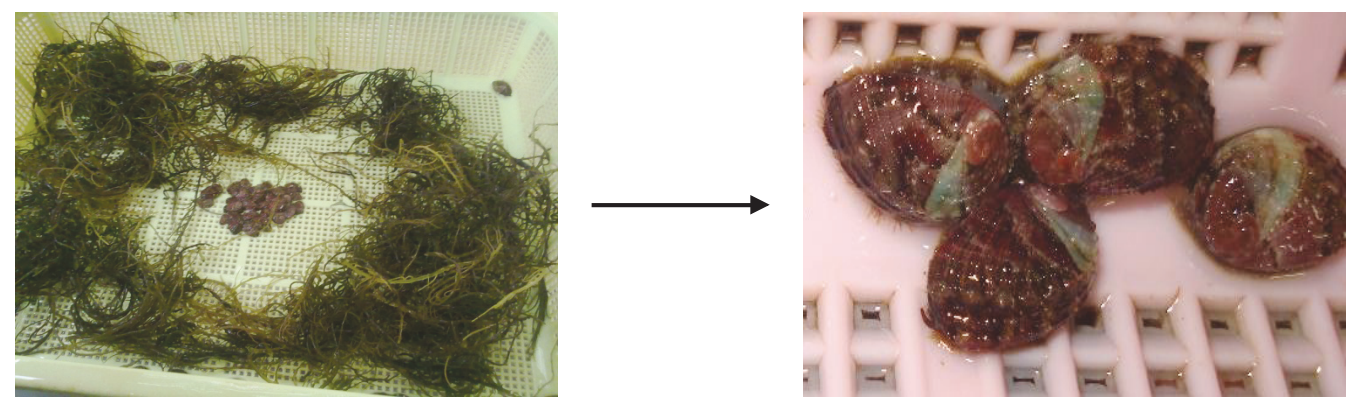

Gracilaria asal tambak (Gracilaria sp. cultured from the pond)
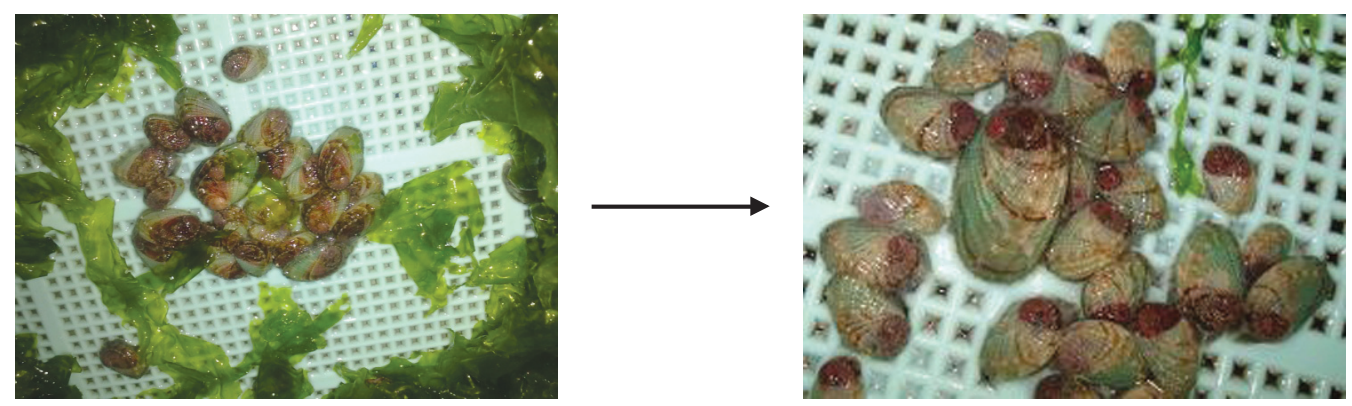

Ulva sp.
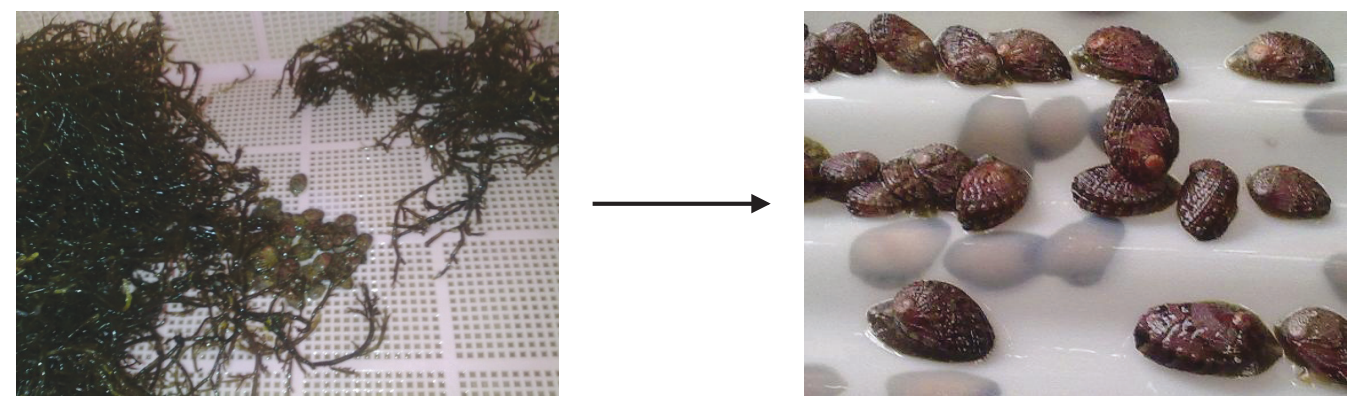

Gracilaria asal laut (Gracilaria origin from the sea)

Gambar 4. Perlakuan Jenis pakan berbeda dan performance dari warna cangkang yuwana abalon Figure 4. Experiment of different food various and colour performance of juvenile abalone shell

komponen penting untuk pertumbuhan (Fleming et al., 1996). Kandungan nutrisi yang terdapat pada pakan sangat berpengaruh bagi pertumbuhan abalon (Fallu, 1991). Menurut Mudjiman (1992), zat- zat gizi yang diperlukan untuk menghasilkan tenaga, mengganti sel- sel tubuh yang rusak dan untuk tumbuh antara lain protein, lemak, karbohidrat, vitamin, mineral, dan air. Zat yang paling berperan dalam pertumbuhan adalah protein.

Abalon memiliki kemampuan yang besar untuk menyintesis lemak dari sumber karbohidrat, akan tetapi untuk meningkatkan pertumbuhan abalon yang baik dibutuhkan makroalga dengan kandungan lemak berkisar antara 3\% 5\%(Mercer et al., 1993).

Lipid memegang peranan penting pada nutrisi abalon sebagai penyedia EPA, khususnya HUFA (High Unsaturated Fatty Acid) (Uki \& Watanabe, 1992). Pada daging abalon mengandung beberapa asam lemak seperti asam palmitat, asam stearat, asam oleat, EPA, dan DHA, kandungan EPA mencapai 12,93\% (Tabel 4). 
Tabel 4. Analisis asam lemak dari daging abalon H. squamata

Table 4. Fatty acid analysis of abalone $\boldsymbol{H}$. squamata meat

\begin{tabular}{lc}
\hline \multicolumn{1}{c}{$\begin{array}{c}\text { Asam lemak } \\
\text { Fatty acid }\end{array}$} & $\begin{array}{c}\text { Daging abalon } \\
\text { Meat of abalone }\end{array}$ \\
\hline Asam palmitat, C16:0 & 31.13 \\
Asam stearat, C18:0 & 8.73 \\
Asam oleat, C18:1 & 7.74 \\
Asam eikosapenta enoat, C20:3n5 (EPA) & 12.93 \\
Asam dekosapenta enoat, C22:6n5 (DHA) & 2.97 \\
\hline
\end{tabular}

Tabel 5. Pengukuran kualitas air pada masing- masing perlakuan

Table 5. Measurement of water quality on each treatment

\begin{tabular}{lcc}
\hline \multicolumn{1}{c}{$\begin{array}{c}\text { Variabel } \\
\text { Variable }\end{array}$} & Minimum & $\begin{array}{c}\text { Maksimum } \\
\text { Maximum }\end{array}$ \\
\hline Suhu (Temperature) $\left({ }^{\circ} \mathrm{C}\right)$ & 29.8 & 31.2 \\
Salinitas (Salinity) $(\mathrm{ppt})$ & 34 & 36 \\
$\mathrm{DO}(\mathrm{mg} / \mathrm{L})$ & 5.0 & 5.4 \\
$\mathrm{pH}$ & 8.1 & 8.56 \\
$\mathrm{NH}_{3}(\mathrm{mg} / \mathrm{L})$ & 0.005 & 0.010 \\
$\mathrm{NO}_{2}(\mathrm{mg} / \mathrm{L})$ & 0.004 & 0.006 \\
\hline
\end{tabular}

Sampai saat ini informasi mengenai kebutuhan asam lemak esensial (EFA) untuk abalon belum tersedia. Asam lemak esensial tidak dapat disintesa oleh tubuh biota melainkan harus disuplai dari pakan. PUFA (Polyunsaturated Fatty Acid) dibutuhkan untuk pertumbuhan normal dan reproduksi abalon yang harus didapatkan dari pakan sebagai asam lemak esensial (Dunstan et al., 1996).

\section{Kualitas Air}

Hasil pengukuran kualitas air selama penelitian disajikan pada Tabel 5. Hasil pengukuran kualitas air selama pemeliharaan menunjukkan bahwa kisaran nilai yang berfluktuasi dan memberikan pengaruh terhadap kehidupan abalon. Hasil pengamatan menunjukkan bahwa suhu dan salinitas, masing-masing cenderung sangat ekstrim karena salinitas air sampai $36 \mathrm{ppt}$, dan suhu air mencapai $31,2^{\circ} \mathrm{C}$.

Pada kondisi suhu di atas $30^{\circ} \mathrm{C}$ dengan periode yang panjang akan mempengaruhi kondisi kesehatan abalon. Menurut Irwan
(2006), suhu yang optimal untuk abalon berkisar antara $24^{\circ} \mathrm{C}-30^{\circ} \mathrm{C}$, sedangkan salinitas optimum antara 30-35 ppt. Menurut Fallu (1991), kisaran salinitas normal yang cocok untuk pertumbuhan abalon yaitu berkisar 33\% 35\%odan pertumbuhan hewan laut tidak optimal pada salinitas di atas 35\%。

\section{KESIMPULAN DAN SARAN}

1. Pemeliharaan yuwana abalon dengan kepadatan dan jenis pakan berbeda memberikan pengaruh yang nyata terhadap pertumbuhan panjang cangkangnya.

2. Pemberian jenis pakan Ulva sp. cenderung lebih baik dalam pertumbuhan panjang cangkang mutlak, sementara pemberian Gracilaria asal tambak selalu lebih baik dibanding dengan Gracilaria asal laut, pada tingkat kepadatan berbeda.

\section{Saran}

Pemeliharaan yuwana abalon disarankan untuk dilanjutkan kembali dengan memberikan jenis rumput laut yang terbaik sebagai pakan abalon sampai ukuran abalon yang lebih besar. 


\section{UCAPAN TERIMA KASIH}

Ucapan terima kasih disampaikan kepada Saudara I Made Buda, Hendra, dan Wiwin sebagai staf teknisi pada hatcheri abalon yang telah membantu selama persiapan sampai selesai pelaksanaan penelitian ini. Terima kasih juga disampaikan kepada Saudara/i Ni Putu Ayu Kenak, Ni Putu Ari Arsini, Ni Kadek Ariani, Darsudi, dan Deny Puji Utami yang telah membantu dalam kegiatan analisis laboratorium.

\section{DAFTAR ACUAN}

Bautista-Teruel, Myrna, N., \& Oseni, M. Millamena. 1999. Diet development and evaluation for juvenile abalone, Haliotis asinina: protein energy levels. Aquaculture, 178: 117- 126.

Boarder, S.J. \& Shpigel, M. 2001. Comparative growth perfomance of juvenil Haliotis roei fed on enriched Ulva rigida and various artificial diets. J. Shellfish Res., 20: 653- 657.

Capinpin, E.C. \& Corre, K.G. 1996. Growth rate of the Philippine abalone, Haliotis asinina fed an artificial diet and macroalgae. Aquaculture, 144: 81- 89.

Chen, H.C. 1984. Recent inovation in cultivation of edible molluscs in Taiwan, with special reference to the small abalone Haliotis diversicolor and the hard clam Meretrix lusoria. Aquaculture, 39: 11- 29.

Dunstan, G.A., Baillie, H.J., Barrett, S.M., \& Volkman, J.K. 1996. Effect of diet on the lipid composition of wild and cultured abalone. Aquaculture, 10: 115- 127.

Effendie, M.I. 1997. Biologi Perikanan. Pustaka Nusatama. Yogyakarta, $163 \mathrm{hlm}$.

Fallu, R. 1991. Abalon Farming. Fishing News Books A Division of Blackwell Scientific Publications Ltd. Osney Mead. Oxford, 195 pp.

Fleming, A.E., Van Barneveldt, R.J., \& Hone, P.W. 1996. The development of artificial diets for abalone: A review and future directions. Aquaculture, 140: 5- 53.

Huchette, S.M.H., Koh, C.S., \& Rob, W.D. 2003. Growth of juvenile blacklip abalone (Haliotis rubra) in aquaculture tanks: effects of density and ammonia. Aquaculture, 219: 457- 470.

Ikenoue, H. \& Kafuku, T. 1992. Modern methods of aquaculture in Japan. Elsevier, Kadansha Ltd. Tokyo, p. 206- 216.
Irwan, J.E. 2006. Pengembangan Budidaya Abalon (Haliotis asinina L.) Produksi Hatcheri di Indonesia. Tesis. Jurusan Perikanan, UNHALU, Kendari, Sulawesi Tenggara, $21 \mathrm{hlm}$.

Mercer, J.P., Mai, K.S., \& Donlou, J. 1993. Comparative studies on the nutrition of two species of abalone, Haliotis tuberculata Linnaeus and Haliotis discus hannai Ino. I. Effect of algal diets on growth and biochemical composition. Invertebt. Reprod. Dev., 23: 75- 88.

Minh, G.D., Petpiroon, S., Jarayabhand, P., Meksumpun, S., \& Tunkijjanukij, S. 2010. Growth and Survival of Abalone, Haliotis asinina Linnaeus 1758, Reared in Suspended Plastic Cages. Kasetsart J. (Nat. Sci.), 44: 621- 630.

Mudjiman, A. 1992. Makanan Ikan. Penebar Swadaya, Jakarta, $190 \mathrm{hlm}$

Natkewatana, A. \& Hylleberg, J. 1985. Thai Spesies of Abalon (Haliotis spp.) is Aquaculture Feasible?. Phuket Marine Biological Center, 7 pp.

Neori, A., Ragg, N.L.C., \& Shpigel, M. 1998. The integated culture of seaweed, abalon and clams in modular intensive land-based systems: II. Performance and nitrogen partitioning within an abalon (Haliotis tuberculata) and macroalgae culture system. Aquaculture Eng., 17: 215- 239.

Priyambodo, B., Sofyan, Y., \& Jaya, I.S. 2005. Produksi Benih Kerang Abalone (Haliotis asinina) Di Loka Budidaya Laut Lombok. Seminar Nasional Tahunan Hasil Penelitian Perikanan dan Kelautan. Perikanan dan Kelautan UGM, Yogyakarta, hlm. 144- 148.

Rahmawati, R., Rusdi, I., \& Susanto, B. 2008. Studi tentang Pertumbuhan Abalon Haliotis squamata (Reeve, 1846) dengan Pemberian Pakan Makroalga yang Berbeda. Prosiding Seminar Nasional Perikanan Sekolah Tinggi Perikanan, $7 \mathrm{hlm}$.

Rusdi, I., Susanto, B., \& Rahmawati, R. 2008. Studi pemberian berbagai jenis pakan makroalga terhadap perkembangan gonad abalon Haliotis squamata (Reeve, 1846). Prosiding Semnaskan Universitas Brawijaya, hlm. 76- 81.

Shpigel, M., Ragg, N.L., Lapatsch, I., \& Neori, A. 1999. Protein content determines the nutritional value of the seaweed Ulva lactuca L. for the abalon Haliotis tuberculata L. and H. discus hannai. J. Shellfish Res., 18: 227- 233. 
Singhagraiwan, T. \& Doi, M. 1993. Seed production and culture of a tropical abalone Haliotis asinina Linne. Department of fisheries, Ministry of Agriculture and Cooperatives. Thai. Mar. Fisheries Res. Bull., 2: 8394.

Soleh, M. \& Murdjani, M. 2007. Budidaya abalon Haliotis asinina L. di bak sistem indoor. Prosiding Seminar Nasional Moluska dalam Penelitian, Konservasi dan Ekonomi, hIm. 65- 73.

Susanto, B., Hanafi, A., Zafran, \& Ismi, S. 2007. Pematangan gonad induk dan perbaikan kualitas benih abalon (Haliotis squamata). Laporan Teknis BBRPBL - Gondol, Bali, 17 hlm.

Susanto, B., Rusdi, I., Ismi, S., \& Rahmawati, R. 2009. Perbenihan dan pembesaran abalon (Haliotis squamata) di Balai Besar Riset Perikanan Budidaya Laut, Gondol, Bali. Prosiding Seminar Nasional Moluska 2. Fakultas Perikanan dan Kelautan. Institut Pertanian Bogor, hlm. 149- 161.
Takashi. 1980. Abalone and their industry in Japan. Ministry of Agriculture. Forestry and Fisheries, p. 165- 177.

Uki, N. \& Watanabe, T. 1992. Review of nutritional requirement of abalone Haliotis spp. and development of more efficient diets. In: Abalone of the world: biology, fisheries and culture. Shepherd, S.A., Tegner, M.J., \& Guzman Del Proo, S.A. (Eds.). Proceedings of the $1^{\text {st }}$ International Symposium on Abalone. Fishing News Books, p. 504- 517.

Vivanco- Aranda, M., Gallardo- Escarate, C.J., \& del Rio- Portilla, M.A. 2010. Low- density culture of red abalone juveniles, Haliotis rufescens Swainson 1822, recirculating aquaculture system and flow-through system. Aquaculture Research, p. 1- 8.

Zhu, W., Mai, K., \&Wu, W. 2002. Thiamin requirement of juvenil abalon Haliotis discus hannai Ino. Aquaculture, 207: 331- 343. 